\title{
Investigating the Link between Economic Complexity Index and Monetary Policy Lending Rates in Selected Sub-Saharan African Countries
}

\author{
O. Ralarala and T. Ncanywa*
}

Department of Economics, University of Limpopo, South Africa

\begin{abstract}
This article investigates if there is a link between economic complexity index and monetary policy lending rates in selected Sub-Saharan African countries. Economic complexity index $(\mathrm{ECl})$ as a measure of productive capabilities and a mix of sophisticated products that countries export, has been found to influence some economic indicators such as economic growth and inequality. Little attention has been paid to ECl's link to lending rates in monetary policy bank lending rate transmission mechanism. In this paper, the ECl-lending rate nexus has been investigated using a panel autoregressive distribution lag methodology. Results indicated a long-run significant relationship with the Kao and Johansen combined cointegration. It was further illustrated in the long-un that ECl estimates have a negative and significant impact on monetary policy lending rates. The series could correct to equilibrium at a significant rate of $25 \%$. These results provided new insights needed for appropriate development economic policy to reduce monetary policy lending rates.
\end{abstract}

Keywords: Monetary policy transmission mechanism, economic complexity index, panel auto-regressive distributed lag model, Sub-Saharan Africa.

\section{INTRODUCTION}

The economic complexity is phenomenon that requires a country to improve its productive capabilities with an aim of exporting a mix of sophisticated products (Hausmann et al., 2014). A country's economic complexity can be improved if it exports not only highly complex products, but also a large number of exclusive products. Hausmann et al., 2014 add that economic complexity index $(\mathrm{ECl})$ has been found to influence some economic indicators such as economic growth and inequality. Little attention has been paid to ECl's link to lending rates in monetary policy bank lending rate transmission mechanism. The bank lending rates form part of the credit channel which consists of the bank-lending channel and the balance sheet channel. The bank lending channel explains how monetary policy shocks affect supply of loans to financial institutions such as banks, while the balance sheet channel deals with loan demands by households and businesses.

The lending rate path in the credit channel of monetary policy transmission mechanism is characterised by ills of moral hazard and adverse selection (Smal and de Jager, 2001). Asymmetric information in financial markets provides the basis for the credit channel of monetary transmission. Bernanke

*Address correspondence to this author at the Department of Economics, University of Limpopo, Private Bag X1106, Sovenga, 0727 South Africa; E-mail: thobeka.ncanywa@ul.ac.za

JEL Codes: E58, O11. and Gertler (1995) offer a detailed description of how imperfections in credit markets may cause a monetary contraction to lead to an increase in the external finance premium faced by borrowers and to a decrease in the loan supply. On the bank lending channel contractionary monetary policy results in lower usable reserve assets at commercial banks (Pétursson, 2001). Tighter monetary policy usually also leads to lower deposits at commercial banks through its impact on economic activity (De Waal and van Eyden, 2012). These factors lower the supply of bank loans available, especially to small firms, thereby adversely affecting investment activity and ultimately economic development.

It had been argued that higher lending rates distort a country's level of investment, reduce the rate of economic growth and are an obstacle to smooth transmission of monetary policy impulse (Bertz and Kerner, 2016; Vernon, 2017; Keynes, 2018). Amer et al. (2018) supports this argument by adding that in response to a country's high lending rates, foreign investors reduce their investments. This is because consumer and business confidence in taking out risky investments is discouraged (Vernon, 2017). Therefore, maintaining lower levels of lending rates will improve a country's investment levels. Despite lending rates, Wuhan and Khurshid (2015) identified other factors that influence investment such as market size, economic development level, investment environmental and preferential policies. Hence, this article attempts to address what can be done to reduce lending rates so as to boost investment. 
The bank lending channel stems from the special role played by banks in the financial system because of their deftness at engaging with certain types of borrowers, primarily small firms. Under these circumstances, the problem of asymmetric information can be especially bigger. In contrast, large firms have recourse to stock and bonds markets and are not necessarily confined to bank intermediation. An important implication is that monetary policy through this channel will have a greater effect on those more dependent on bank loans, such as smaller firms, since larger firms have recourse to obtaining funds by issuing new share capital (Smal and De Jager, 2001). As circumstances and restrictive regulatory frameworks change to allow banks greater ability to raise funds, the potency of this channel will be reduced (Mishkin, 1995).

Monetary policy affects the value of firms' assets through their balance sheets (Smal and De Jager, 2001). According to Łyziak (2010), there is a negative relationship between interest rates and financial asset prices. A rise in the rate of interest lowers cash-flow and leads to a fall in financial asset prices. This process results to lower investment spending. Monetary policy operates through both the demand for and the supply of loans. Therefore, when the firm's balance sheets are weak, moral hazard and adverse selection problems are reduced, but the availability of funds for borrowing firms will also be reduced. The "lemons" problem associated with asymmetric information about loan quality makes bank loans illiquid, and the absence of a secondary market for government securities makes those instruments illiquid as well (Jan, 2018). The bank therefore values reserves because they provide the only available liquid buffer against unanticipated deposit withdrawals.

Over the years, various monetary policy regimes have been applied as a way of trying to achieve the monetary stability required for balanced and sustainable economic growth in SSA. Adam et al., 2010 explain that in SSA, only three countries adopted the inflation targeting monetary policy framework, including South Africa. Kenya currently has a hybrid monetary policy framework involving elements of both inflation targeting and monetary targets (Adam et al., 2010). Tanzania, Mozambique and Nigeria are all using the monetary targeting framework. As much as different countries target different monetary policy frameworks, they all share an objective of maintaining price stability in the interest of sustainable and balanced economic development and growth (Anwar and Nguyen, 2018).
Monetary policy affects the volume of liquid funds in the economy as Petursson (2001) contends that when the central bank raises its policy rate, the opportunity cost of holding such liquid assets increases. This occurs because other interest-bearing financial assets have become more attractive compared with liquid funds. The demand for liquid funds should therefore decrease. A higher policy rate could also affect the demand for broad money because a rise in the policy rate will push up interest rate on both securities and broad money (Chen et al., 2016; Mishkin, 1995) Nonetheless, all things being equal, a rise in the policy rate would lead to a lower price level and a reduction in income and wealth hence reducing the demand for money. The bank lending channel stems from the special role played by banks in the financial system because of their deftness at engaging with certain types of borrowers, primarily small firms (Chingano, Manaresi and Sette, 2016). It put an emphasis on the argument that adjustments on the policy rate affect the lending rate on retail financial products (Eggertsson et al., 2019; Bernanke and Gretler, 1995). As a result, once a country's reserve bank changes the policy rate, domestic banks are inclined to follow suit by changing their lending rates. In response to the adjustments in lending rates, firms and individuals also could alter their investment and spending patterns (Mahadeva and Sinclair; 2001).

Atlas of Economic Complexity revealed that there had been improvements in economic complexity of Sub-Saharan African countries compared to that of the past decades (Hausmann et al., 2014). This could be due to advancement in the production of goods and services a country exports, including their capabilities on knowledge, human capital and technology (Hausmann and Hidalgo, 2011). Thus, this article investigates if there is a link between economic complexity index and monetary policy lending rates in some selected Sub-Saharan African countries (South Africa, Nigeria, Mozambique, Kenya and Tanzania). The selected countries were chosen due to availability of data of the selected variables in the study period. In a nutshell, it was imperative to find out whether a longrun and short-run relationship exists between economic complexity and monetary policy lending rates; and to estimate the effects in the nexus. The paper is structured as follows, this section is followed by discussing trends of lending rates and economic complexity of selected sub-Saharan countries, then reviewed empirical and theoretical literature, methodology and data issues, results and discussion, lastly conclusion and recommendations. 
LLR

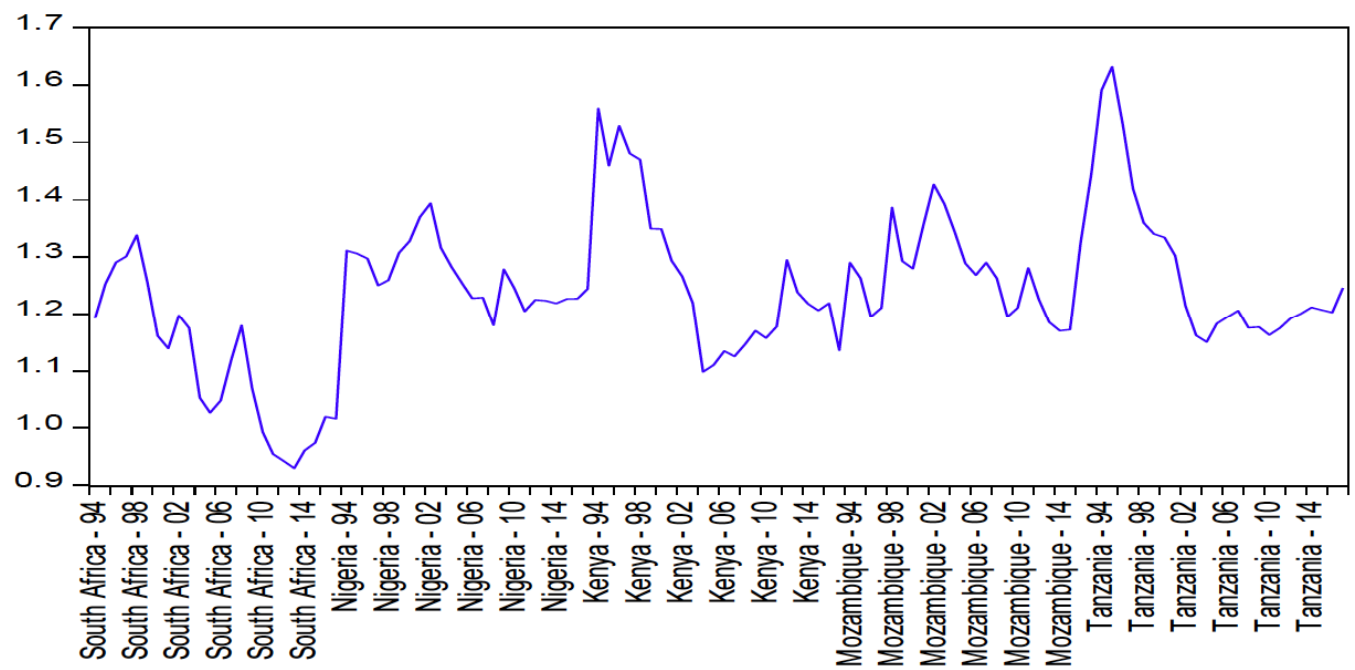

Figure 1: lending rate trends in selected SSA countries.

Source: Author compilation from World Bank, 1994-2017.

Notes: LLR lending rates.

\section{TRENDS IN ECI AND MONETARY POLICY LENDING RATES IN SELECTED SSA COUNTRIES}

Figure 1 depicts the lending rates trends in selected SSA countries (South Africa, Nigeria, Kenya, Mozambique and Tanzania).

From Figure 1, it can be seen that South Africa has the lowest lending rates compared to the countries selected and Tanzania with general highest lending rates. It has been observed that the selected countries have highest lending rates in 1998 . This could be due to the fact that in 1998 banks lent high risk loan and charged high interest rate and later changed this behaviour (Anwar and Nguyen, 2018). According to Banu (2013), high lending rates have negative effects on investment, economic growth and consumer spending in an economy. In the long-run, this might also trigger financial instability and global financial

$\mathrm{ECI}$

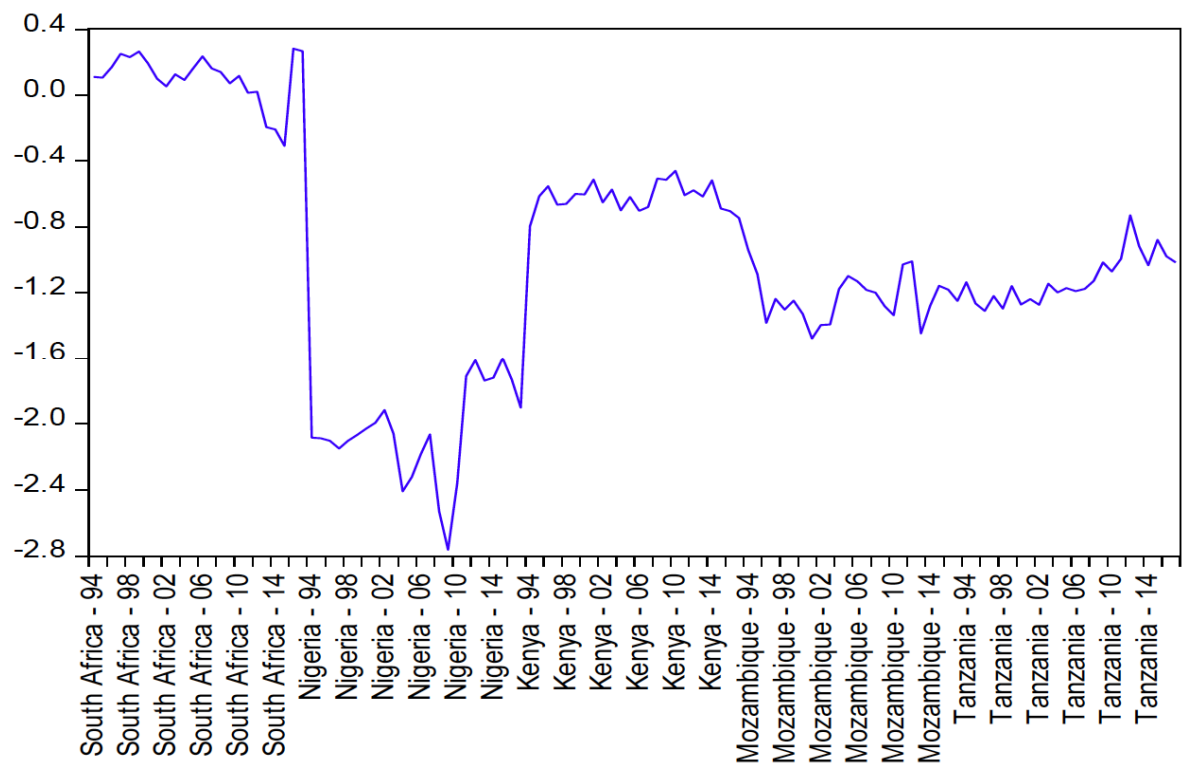

Figure 2: ECI trends in selected SSA countries.

Source: Author compilation from World Bank, 1994-2017.

Notes: ECI Economic Complexity Index. 
crisis. Hence, it was interesting to find out if economic development tools such as economic complexity would reduce escalating lending rates.

Figure 2 depicts trends in economic complexity index of the selected Sub-Saharan African countries. South Africa appears to have the highest ECl over all the selected periods followed by Kenya and Nigeria appears to have the lowest $\mathrm{ECl}$. These findings are in line with the $\mathrm{ECl}$ rankings provided by the Atlas of $\mathrm{ECl}$ (Hausmann et al., 2014). The Atlas revealed that from the $2009 \mathrm{ECl}$ rankings, South Africa was ranked number 55; Kenya, 73; Tanzania, 95; Mozambique, 109; and Nigeria ranked 122. It is further reported that developed economies such as Japan, the United Kingdom and the United States of America are ranked with the highest $\mathrm{ECl}$ compared to developing countries such Sub-Saharan African countries. This entails that SSA countries need to focus more on shifting their production from agricultural and extractive industries to more sophisticated industries. Economic complexity addresses the question of why some countries progress very slowly by studying the characteristics of their export baskets. SSA countries are known for being rich in natural resources such as crude oil, agricultural products, diamond and gold. Despite the fact that Africa is a natural resource rich continent, there is a need for structural transformations by exporting complex products (Hausmann et al., 2014). Hartmann et al. (2017) argued that countries exporting more complex products tends to be more inclusive and could influence many economic indicators. This is the reason why in this article there is exploration of the relationship between economic complexity and monetary policy lending rates.

\section{LITERATURE REVIEW}

\subsection{Theoretical Literature}

Different views on monetary policy transmission mechanism began with the classical theory view as explained by Fisher (1930). Under this theory, variables such as output and employment are immune to changes in money supply. This analysis was based on the inverse relationship money and prices hold. When money supply increased the price level rises proportionally. The quantity theory equation is written as follows:

$V=\frac{P \times Y}{M}$
Where $M$ is the money supply; $P$ is the average price level over a given period, $V$ the income velocity of circulation of money, and $Y$ is the volume of transactions of goods. The term $P \times Y$ represents current nominal output. The classical economists believed that the economy is always at, or near the natural level of real output (Fransisco, 1999; Mishkin, 1995). As a result, the classical argument assumes that $\mathrm{Y}$ and $\mathrm{V}$ are fixed. This implies that if a country's reserve bank was to engage in monetary policy, the effects of an increase in money supply can only increase the price level. In other words, expansionary monetary policy can only lead to inflation; and contractionary monetary policy can lead to deflation of the price level. The fiscal policy has no role and has no influence whatsoever on the price level. Classical economists believed that the role of monetary policy is limited and has no influence on the real economy (Smal and de Jagar, 2011). However, the quantity of money has some weaknesses. The classical quantity theory assumes that there is a correlation between changes in the amount of money and changes in spending. Critics of the quantity theory have suggested that this correlation exists because changes in the amount of money by circulation are caused by, rather than the causes of, changes in business activity (Mishkin, 1995).

The Keynesians had a different view from the classical view, they claimed that monetary policy transmission had an indirect effect on variables such as money supply and aggregate demand (Smal and De Jager; 2001). This effect took place through changes in the interest rate which trigger changes in output and money supply. In the Keynesian transmission mechanism, there exist a link between the monetary sector and the real sector. Different chain reactions can be linked together to explain most macroeconomic changes in these two sectors. The link in the chain is from the monetary sector (money market) to the real sector (goods market). The changes in the monetary sector were caused by changes in the interest rate and impact investment which later influences aggregate expenditure and real GDP. Sterk and Steyrero (2018) put an emphasis on an importance of this sequence in the analysis of the consequences of monetary policy steps.

Lastly, unlike Keynesians, monetarists believe in direct transmission mechanism (Bernanke and Gretler 1995). Monetarists argue that if money supply increases, people will hold more money than they prefer to hold. The surplus money is therefore spent in 
the purchase of securities, goods and services thus leading to an increase in aggregate demand. The monetarists argue that the transmission mechanism is significant for controlling money supply and aggregate demand in the long-run. This happens through portfolios used by different players in the economy such as households and firms to hold their wealth (Taylor, 1995). Monetarists also view the indirect operation of the transmission mechanism operation but with different assumptions from those of the Keynesians. They first assume that the liquidity preference curve is relatively inelastic and then assume that the investment demand curve is relatively elastic. Monetarists believe that this transmission mechanism indirect operation is stronger than the Keynesians view it, as a result, the effect of monetary policy on aggregate demand is much greater than the Keynesians perceived. Monetarists believe that persistent fluctuations are purely monetary phenomena brought about by persistent expansionary or contractionary monetary policies. The central bank conducts monetary policy as a way of keeping the growth rate of money supply fixed at a rate that is equal to the real growth rate of the economy over a given period.

\subsection{Empirical Literature}

As much as there is a variety of studies that investigated the lending rates of monetary policy transmission (Morais et al., 2019; Ciccarelli et al., 2015; Bernanke and Gertler, 1995) and economic complexity index (Hidalgo and Hausmann, 2009; Hausmann et al., 2014; Hidalgo, 2015), currently literature lacks evidence concerning the link between the two. For instance, Khan (2010) investigated the design and effects of monetary policy in Sub-Saharan African countries, and whether the credit channel has any impact on output and investment on the selected 20 Sub-Saharan African countries. It was found that the credit channel is considered a good predictor of future movements in investment and output. It is widely argued that due to low financial development in SubSaharan countries, the implications of monetary policy are not as strong as in the developed countries. Mishra et al. (2010) for example, added that as a result of the poor development of domestic securities markets in most Sub-Saharan African countries, the interest rate channel is expected to be weak. Also, small and illiquid markets for assets such as equities and real estate would tend to weaken the asset channel. In general, it was attested that the banking lending channel should be the dominant mode of monetary transmission in lowincome countries.

On the other hand, when Hidalgo (2009) investigated the dynamics of economic complexity, it was found that economic complexity is of great importance due to its ability to predict future economic growth and explain differences in the level of income of a country. Hanushek (2013) discovered that if a country has limited knowledge and skills, it is quite challenging for it to manufacture nuclear reactors or technologically advanced machines of even low quality. The above findings emphasize the importance of an economy to produce complex product with the aim to stimulate its economic growth. Hausmann et al. (2014) added that the mix of products that countries make or export has been shown to be a strong leading indicator of economic growth. Hence, it was interesting to find the existence of a relationship between economic development (economic complexity) and monetary policy lending rates. Simoes and Hidalgo (2011) argued that economic complexity could be an analytical tool for understanding the dynamics of economic development. The tool was found to be very crucial in helping economies understand the evolution of countries' productive structures and trade partners.

Traditionally, monetary rules have been based on the behaviour of monetary instruments. However, as Gomanee et al. (2003) put it, due to economic diversification and improvement in market sophistication asset, markets instrument-based rules have become more difficult to implement. With regard to economic complexity, Hartmann (2017) supports this argument by emphasizing that while economic diversification can provide valuable new social choices and capabilities, it also tends to lead to more complex decision processes and changes to the set of capabilities required by people to self-determine their future. Within this process of structural transformation, social networks are crucial for accessing information and social support, but networks can also be a root cause of exclusion and inequality reproduction. This implies the need to encourage innovation and economic diversification beyond production expansion, focusing on the promotion of human agency and social inclusion.

With the literature reviewed above, it can be suggested that economic complexity has an effect on a number of macroeconomic variables including output, investment and income inequality (Hidalgo and Hausmann, 2009; Hausmann et al., 2014; Hidalgo, 
2015). It has been shown that economic complexity is positively related with a country's economic growth (Metcalfe and Foster 2007). Furthermore, evidence of a link between monetary policy lending rates and a variety of macroeconomic variables such as GDP, investment and income inequality has been provided (Hartmann et al., 2017). So, we are going to investigate what economic complexity can do for lending rates in a panel data analysis.

\section{METHODOLOGY}

\subsection{Model Specification}

This study used yearly data and quantitative research design to determine if economic complexity can influence monetary policy lending rates in some selected Sub-Saharan Africa countries (South Africa, Nigeria, Mozambique, Kenya and Tanzania). The study period investigated spans from 1994 to 2017. Both the period and the countries were selected due to the availability of data. Data for lending rates was found from Quantec SA Easy Data; for ECl it was obtained from the Atlas of Economic complexity and data for gross fixed capital formation and foreign direct investment was obtained from the World Bank.

The compilation of this model may seem complex since there is little to no theory linking economic complexity to monetary policy lending rates. We made lending rates the function of economic complexity index because the study investigates whether there exists a relationship between these variables. The model also states that lending rates is a function of gross fixed capital formation and foreign direct investment. Both Classical and Keynesian agree that lending rates have a negative effect on a country's investment decision. A country with lower interest stimulates the investment opportunities for domestic investors. Higher domestic investment leaves little room for the foreign investors, so lending interest rate can be used to determine FDI flows. To achieve the objectives of the study, the following model was adopted:

$$
L R_{i t}=f\left(E C I_{i t}+G F C F_{i t}+F D I_{i t}\right)
$$

Equation 2 states that lending rates $\left(L R_{i t}\right)$ is a function of economic complexity index $\left(E C I_{i t}\right)$, gross fixed capital formation $\left(G F C F_{i t}\right)$ and foreign direct investment $\left(F D I_{i t}\right)$. Making equation 2 linear, we acquire our final model as:

$$
L L R_{i t}=\alpha+\beta_{1} E C I_{i t}+\beta_{2} L G F C F_{i t}+\beta_{3} F D I_{i t}+\varepsilon
$$

Where $\alpha$ is a constant; $\beta$ is a coefficient for each explanatory variable; $L$ is logarithm to standardize the variables in values; and $\varepsilon$ is an error terms. A negative relationship between $\mathrm{ECl}$ and monetary policy lending rates is expected while gross fixed capital formation and foreign direct investment are expected to be positively related to lending rates.

\subsection{Panel Unit Root Tests}

The study employed three panel unit root tests namely Levin, Lin and Chu (2002) (LLC) test; Im, Pesaran, Shin (2003) (IPS) test; and the Fisher- ADF test (Maddala and $\mathrm{Wu}, 1999$ ). The alternative hypothesis for the Levin et al. (2002) test is that there is stationary in all the series and for the Maddala and $\mathrm{Wu}$ (1999) test is that there are unit roots in some, but not necessarily all the series. Panel unit root tests are advantageous compared to individual time series unit root tests due to their standard normal asymptotic distribution. Additionally, Maddala and Wu (1999) argued that these tests allow for infinite or finite number of cross-sections; the time series can be of different length; and they allow groups to be integrated of different orders. The Im-Pesaran-Shin (IPS) test was chosen because it relaxes the restrictive assumption of the LLC test (Perasan, 2007). Moreover, the IPS is argued to allow for heterogeneous panels and propose panel unit root tests which are based on the average of the individual ADF (Augmented Dickey-Fuller) unit root tests computed from each time series. In contrary, both the LLC and IPS tests have been criticised for requiring cross-sectional independence (Baltagi, 2008). For testing stationarity as a null, $\mathrm{Yu}$ and Lee, (2010) suggests that of the Fisher test be and also in testing for cointegration in panel data. Madalla and Wu (199) pointed the importance of combining $p$-values from a unit root test applied to each selected SSA country. This approach of combining $\mathrm{P}$-values allows us to devise panel unit root tests under the aforementioned general assumptions.

\subsection{Panel Cointegration}

The study adopted the Pedroni, the Kao and the Johansen-Fisher tests for cointegration. The first two tests (Kao and Pedroni) assumed as null and alternatives hypotheses that either all the relationships are cointegrated or not (Pedroni, 1999; 2004; Kao, 1999). Kao (1999) suggested that two DF statistics assumed strict exogeneity of the explanatory variables with respect to the errors in the equation, while the other two permit for endogeneity of the explanatory 
variables. The Johansen Fisher panel cointegration test is a panel version of the individual Johansen cointegration test (Madalla and Wu, 1999). It was further added that Johansen Fisher panel cointegration test performs way better compared to the Pedroni and Kao tests for cointegration due to its flexibility, simple implementation and being intuitively appealing.

\subsection{Panel ARDL}

The panel unit root tests estimated in the study showed that the variables are differentiated of different orders of cointegration but none of them is I (2). This paved a way for the study to employ the panel ARDL approach. The panel ARDL approach was used to estimate the long and short run relationship between monetary policy lending rates and economic complexity. According to Perasan, Shin, and Smith, (2001), the panel ARDL model can be written as:

$\Delta y_{i, t}=\phi_{i} E C_{i, t}+\sum_{j=1}^{q-1} \Delta X_{i, t-1} \beta_{i, j}+\sum_{j=1}^{p-1} \lambda_{i, j} * \Delta y_{i, t-j}+\varepsilon_{i, t}$

Where

$E C_{i, t}=\Delta y_{i, t-1}-X_{i, t}{ }^{\prime} \theta$

The assumptions are that both the dependent variable and the controlled variables have the same number of lags in each cross section and that the controlled variables have the same number of lags $q$ in each cross section, but this assumption is not strictly required for estimation (Perasan et al., 2001). The ARDL approach was also chosen due to its advantages such as its ability to incorporate variables integrated of different orders. The ARDL also treats all variables as dependant variables. This implicitly allows each variable to be endogenous, thereby violating the weak exogeneity condition of the bounds testing framework (McNown, 2016). A further advantage of the ARDL test is that it eliminates inconclusive inferences with the bounds test.

\section{RESULTS AND DISCUSSIONS}

\subsection{Panel Unit Root Tests}

The study adopted the Levin, Lin, Chu test; the Im, Perasan, Chin test and the Fisher-ADF test for stationarity to check for unit root. The results from the tests are summarized in Table 1.

Table 1 presents the summary of panel unit root test results as estimated using the Levin, Lu, Chu; Im,
Perasan, Chin; and Fisher- ADF. Table 1 shows that variables under investigation are integrated of different orders $[I(0)$ and $I(1)]$ but none of them is $I(2)$. Lending rates $(L L R)$ and economic complexity index $(E C l)$ are integrated of order zero; whereas gross fixed capital formation and foreign direct investment are integrated of the first order. This gives way forward to run the panel ARDL model (Perasan, et al., 2001). It was added that panel ARDL approach is advantageous in the sense that it emphasizes and allows for the possibilities of estimating different variables with different order of stationarity.

\subsection{Panel Cointegration Test Results}

Tables $\mathbf{2 a}, \mathbf{2} \mathbf{b}$ and $\mathbf{2 c}$ provide summarized results of panel cointegration tests as estimated under the Pedroni, Kao and Johansen-Fisher tests for cointegration respectively. All three tests show the existence of cointegration between monetary policy lending rates and $\mathrm{ECl}$.

The study tested cointegration using three approaches, the Pedroni, the Kao and the JohansenFisher panel cointegration tests as reported in Tables $\mathbf{2 a}, \mathbf{2 b}$ and $\mathbf{2 c}$ respectively. This was done to check whether the variables of interest will still move together to the same direction in the long-run (Dickey et al., 1994). The estimated model included monetary policy lending rates, the economic complexity index, gross fixed capital formation and foreign direct investment. The Kao estimated a probability value of 0.0021 which is significant at $5 \%$ levels. Thus it showed an existence of cointegration and we reject the null hypothesis of no cointegration at $5 \%$ level. The Johansen-Fisher for cointegration tests are consistent with the Kao, they showed an existence of cointegration amongst the variables. The Pedroni showed no cointegration between the variables.

\subsection{ARDL Long-Run Results}

Table 3 summarises the long-run panel ARDL results for the selected SSA countries. The long-run relationship was tested between lending rates and economic complexity index. Table 4 shows an existence of a negative but significant long-run relationship between lending rates and economic complexity index. This can be interpreted as, ceteris paribus, a $1 \%$ increase in economic complexity will lead to $12 \%$ decrease in lending rates. The probability value confirms the significance of this relationship. High lending rates are undesirable for economies as they 
Table 1: Summary of Panel Unit Root Test Results

\begin{tabular}{|c|c|c|c|c|}
\hline VARIABLE & TEST & TEST EQUATION & LEVEL & $1^{\text {sT }}$ DIFFERENCE \\
\hline \multirow[t]{6}{*}{$L L R$} & LEVIN, LIN, CHU & Individual and intercept & 0.0000 & - \\
\hline & & None & 0.0008 & - \\
\hline & IM, PESARAN, CHIN & Individual and intercept & 0.0000 & - \\
\hline & Fisher- ADF & Individual and intercept & 0.0000 & - \\
\hline & & Individual, intercept and trend & 0.0009 & - \\
\hline & & None & 0.0054 & - \\
\hline \multirow[t]{4}{*}{$E C l$} & LEVIN, LIN, CHU & Individual and intercept & 0.0026 & - \\
\hline & & Individual, intercept and trend & 0.0035 & - \\
\hline & Fisher- ADF & Individual and intercept & 0.0012 & - \\
\hline & & Individual, intercept and trend & 0.0082 & - \\
\hline \multirow[t]{5}{*}{ LGCFC } & LEVIN, LIN, CHU & Individual and intercept & 0.3095 & 0.0000 \\
\hline & & Individual, intercept and trend & 0.2108 & 0.0000 \\
\hline & & None & 0.1770 & 0.0000 \\
\hline & IM, PESARAN, CHIN & Individual and intercept & 0.3237 & 0.0000 \\
\hline & & Individual, intercept and trend & 0.0890 & 0.0000 \\
\hline \multirow{6}{*}{$F D I$} & & None & 0.0077 & - \\
\hline & IM, PESARAN, CHIN & Individual and intercept & 0.0054 & - \\
\hline & & Individual, intercept and trend & 0.0519 & - \\
\hline & Fisher- ADF & Individual and intercept & 0.0135 & - \\
\hline & & Individual, intercept and trend & 0.0912 & - \\
\hline & & None & 0.1152 & 0.0000 \\
\hline
\end{tabular}

Source: Author's compilation from E-views.

Notes: LLR logged lending rate; ECI economic complexity index; LGCFC logged gross fixed capital formation; FDI foreign direct investment.

Table 2a: Summary of Pedroni Cointegration Test Results

\begin{tabular}{|c|c|c|}
\hline Variable & T-statistics & P-value \\
\hline \hline Panel v-Statistic & -1.086608 & 0.8387 \\
\hline Panel rho-Statistic & 1.507949 & 0.9121 \\
\hline Panel PP-Statistic & 0.454371 & 0.7511 \\
\hline Panel ADF-Statistic & -1.570461 & 0.1481 \\
\hline
\end{tabular}

Source: Author, with e-views 9.5 computation. 
Table 2b: Summary of Kao Panel Cointegration Test Results

\begin{tabular}{|c|c|c|}
\hline Variable & T-statistics & P-value \\
\hline \hline ADF & -2.856343 & $0.0021^{\star *}$ \\
\hline Residual variance & 6.966409 & \\
\hline HAC variance & 6.395610 & \\
\hline
\end{tabular}

Source: Author, with e-views 9.5 computation.

Table 2c: Summary of Johansen-Fisher Panel Cointegration Test Results

\begin{tabular}{|c|c|c|c|c|}
\hline $\begin{array}{c}\text { Hypothesized no. of } \\
\text { CE(s) }\end{array}$ & $\begin{array}{c}\text { Fisher stat. } \\
\text { (from trace test) }\end{array}$ & Probability & $\begin{array}{c}\text { Fisher stat. } \\
\text { (from 0 max-eigen test) }\end{array}$ \\
\hline \hline None & 49.56 & $0.0000^{* * *}$ & 41.06 & $0.0000^{* * *}$ \\
\hline At most 1 & 19.20 & $0.0185^{* *}$ & 15.05 & 0.1820 \\
\hline At most 2 & 11.72 & 0.1229 & 11.45 & 0.3237 \\
\hline At most 3 & 7.626 & $0.0281^{* *}$ & 7.626 & 0.0281 \\
\hline
\end{tabular}

Note: ${ }^{*},{ }^{* *}$, and ${ }^{* * *}$ indicate that the p-values are significant at $10 \%, 5 \%$ and $1 \%$ level of significance respectively. The fisher's test applies regardless of the dependent variable.

Table 3: Summary of Long-Run Panel ARDL Estimates

\begin{tabular}{|c|c|c|c|}
\hline Variables & Coefficient & Std. Error & Prob.* Statistic \\
\hline \hline ECI & -0.124472 & 0.022791 & -5.461418 \\
\hline LGFCF & -0.008121 & 0.001276 & 45.56399 \\
\hline FDI & 0.866345 & 0.019014 & -6.363906 \\
\hline
\end{tabular}

Source: Author, with e-views 9.5 computation.

Table 4: Summary of Short-Run Panel ARDL Estimates and ECM

\begin{tabular}{|c|c|c|c|c|}
\hline Variables & Coefficient & Std. Error & t-Statistic & Prob.* \\
\hline \hline ECT(-1) & -0.257036 & 0.136004 & -1.889912 & 0.0639 \\
\hline $\mathrm{D}(\mathrm{ECl})$ & 0.010426 & 0.019759 & 0.527639 & 0.0012 \\
\hline $\mathrm{D}(\mathrm{ECl}(-1))$ & 0.148993 & 0.043764 & 3.404474 & 0.3102 \\
\hline $\mathrm{D}(\mathrm{LGFCF})$ & 0.008321 & 0.008127 & 1.023867 & 0.5998 \\
\hline $\mathrm{D}(\mathrm{LGFCF}(-1))$ & 0.012180 & 0.005723 & 2.128438 & 0.0376 \\
\hline $\mathrm{D}(\mathrm{FDI})$ & 0.261914 & 0.408432 & 0.641268 & 0.1273 \\
\hline
\end{tabular}

Source: Author, with e-views 9.5 computation.

increase the cost of borrowing and can lead to high inflation rates and low levels of investments. This is in line with literature debates that there exists a link between the monetary sector and the real sector (Hidalgo and Hausmann, 2009; Hausmann et al., 2014; Hidalgo, 2015; Sterk and Steyrero, 2018).

Investment forms part of the gross domestic product, therefore if it increases, aggregate demand also increases. Net investment, for example, increases the capacity of production (Pollin, Epstein and Ndikumana, 2009). An increased production capacity leads to an increase in ECl. Khan (2010) suggests that the lending rate can be used to predict future patterns in economic growth. At the same time, increased economic complexity is associated with rapid economic growth and steady economic development (Hidalgo, 2009). A negative but significant long-run relationship was also revealed between lending rates and gross fixed capital formation whereas lending rates and 
foreign direct investment are shown to be positively and significant at $1 \%$ levels.

\subsection{ARDL Short Term Results and ECM}

Table 4 shows the error correction term (ECT) of the model and the summary of the short run relationship between lending rates and economic complexity. The ECT proves that the model holds the requirement for a negative sign which means that the model will subsequently correct itself over time, adjust and reach equilibrium. Therefore, the model is adequately formulated, and we can rely on the estimates. The speed of adjustment is estimated at $25 \%$ and is significant at $10 \%$ level. This implies that the model will reach equilibrium at some point in time. In the short run, the panel ARDL test showed a positive and significant relationship between lending rates and economic complexity.

\section{CONCLUSION AND RECOMMENDATIONS}

The study aimed to investigate a link between monetary policy lending rates and economic complexity in five selected SSA countries for the period 1994 to 2017. The study adopted the ARDL panel approach and used the IPS, LLC and Fisher-ADF tests to test for unit root. Variables were found to be integrated of different orders but none of them were integrated of the second order. The Pedroni, Kao and Johansen-Fisher tests were used to estimate cointegration in the panel data. The Kao and Johansen-Fisher for cointegration confirmed the existence of cointegration between lending rates and $\mathrm{ECl}$, which implied a long run relationship. The panel ARDL approach was used to find long and short run estimates in the relationship among the variables of interest.

From a policy perspective, for SSA countries to increase their economic complexity, they have to focus on producing and exporting more sophisticated products. They also need to pay more attention in product diversification. A country's economic complexity is also increased if it exports a large number of different products. The effectiveness of monetary policy in SSA needs to be enhanced so as to achieve the monetary policy goals. This can be done by increasing competition and reducing concentration in the bank markets. The banks in more concentrated markets are likely to exhibit greater interest rates rigidity. Additionally, the study suggests that the SSA must be developed in order to avoid the problems of asymmetric information in lending rates. All monetary policy frameworks adopted in the SSA must be characterized by transparency. Bank lending rate adjusts during period of monetary expansion or easing but it does not adjust during period of monetary contraction or tightening.

Future research can focus on investigating whether the monetary policy transmission mechanism has any effects on product space capabilities in SS.

\section{REFERENCES}

Adam, C., Collier, P. and Ndung'u, N., 2010. Kenya: Policies for prosperity. Oxford University Press.

Ammer, J., Claessens, S., Tabova, A. and Wroblewski, C., 2018. Home Country Interest Rates and International Investment in Safe and Risky US Bonds. https://doi.org/10.17016/IFDP.2018.1231

Anwar, S. and Nguyen, L.P., 2018. Channels of monetary policy transmission in Vietnam. Journal of Policy Modeling, 40(4), pp.709-729.

https://doi.org/10.1016/j.jpolmod.2018.02.004

Baltagi, B., 2008. Econometric analysis of panel data. John Wiley \& Sons.

Banu, I.M., 2013. The impact of credit on economic growth in the global crisis context. Procedia Economics and Finance, 6, pp.25-30.

https://doi.org/10.1016/S2212-5671(13)00109-3

Bernanke, B.S. and Gertler, M., 1995. Inside the black box: the credit channel of monetary policy transmission. Journal of Economic perspectives, 9(4), pp.27-48. https://doi.org/10.1257/jep.9.4.27

Betz, T. and Kerner, A., 2016. The influence of interest: Real US interest rates and bilateral investment treaties. The Review of International Organizations, 11(4), pp.419-448 https://doi.org/10.1007/s11558-015-9236-6

Chen, Q., Filardo, A., He, D. and Zhu, F., 2016. Financial crisis, US unconventional monetary policy and international spillovers. Journal of International Money and Finance, 67, pp.62-81. https://doi.org/10.1016/j.jimonfin.2015.06.011

Ciccarelli, M., Maddaloni, A. and Peydró, J.L., 2015. Trusting the bankers: A new look at the credit channel of monetary policy. Review of Economic Dynamics, 18(4), pp.979-1002. https://doi.org/10.1016/j.red.2014.11.002

Cingano, F., Manaresi, F. and Sette, E., 2016. Does credit crunch investment down? New evidence on the real effects of the bank-lending channel. The Review of Financial Studies, 29(10), pp.2737-2773 https://doi.org/10.1093/rfs/hhw040

Cristelli, M., Tacchella, A. and Pietronero, L., 2015. The heterogeneous dynamics of economic complexity. PloS one, 10(2), p.e 0117174. https://doi.org/10.1371/journal.pone.0117174

De Waal, A. and van Eyden, R., 2012. The monetary transmission mechanism in South Africa: A VECM augmented with foreign variables. University of Pretoria. https://doi.org/10.1111/saje.12027

Dickey, D.A., Jansen, D.W. and Thornton, D.L., 1994. A Primer on Cointegration with an Application to Money and Income. In Cointegration (pp. 9-45). Palgrave Macmillan, London. https://doi.org/10.1007/978-1-349-23529-2_2

Durlauf, S.N., 1998. What should policymakers know about economic complexity? Washington Quarterly, 21(1), pp.155-165 https://doi.org/10.1080/01636609809550300 
Eggertsson, G.B., Juelsrud, R.E., Summers, L.H. and Wold, E.G., 2019. Negative nominal interest rates and the bank lending channel (No. w25416). National Bureau of Economic Research. https://doi.org/10.3386/w25416

Fisher, I., 1930. Theory of interest: as determined by impatience to spend income and opportunity to invest it. Augustusm Kelly Publishers, Clifton.

Fransisco, L., (1999). The transmission mechanism of monetary policy in a stabilizing economy: Notes on the case of Brazil

Gomanee, K., Morrissey, O., Mosley, P., \& Verschoor, A. (2003). Aid, pro-poor government spending and welfare. Credit research paper no. 3. Nottingham: University of Nottingham. https://doi.org/10.2139/ssrn.412244

Hanushek, E.A., 2013. Economic growth in developing countries: The role of human capital. Economics of Education Review, 37, pp.204-212. https://doi.org/10.1016/j.econedurev.2013.04.005

Hartmann, D., Guevara, M.R., Jara-Figueroa, C., Aristarán, M. and Hidalgo, C.A., 2017. Linking economic complexity, institutions, and income inequality. World Development, 93, pp.75-93.

https://doi.org/10.1016/j.worlddev.2016.12.020

Hausmann, R. and Hidalgo, C.A., 2011. The network structure of economic output. Journal of Economic Growth, 16(4), pp.309-342. https://doi.org/10.1007/s10887-011-9071-4

Hausmann, R., Hidalgo, C.A., Bustos, S., Coscia, M., Simoes, A. and Yildirim, M.A., 2014. The atlas of economic complexity: Mapping paths to prosperity. Mit Press. https://doi.org/10.7551/mitpress/9647.001.0001

Hidalgo, C.A., 2009. The dynamics of economic complexity and the product space over a 42 year period (No. 189). Center for International Development at Harvard University.

Hidalgo, C.A. and Hausmann, R., 2009. The building blocks of economic complexity. Proceedings of the national academy of sciences, 106(26), pp.10570-10575. https://doi.org/10.1073/pnas.0900943106

Jan, C., 2018. The Evolution of the Online Marketplace, and Its Viability as an Institutional Asset Class (Doctoral dissertation, Harvard University)

Kao, C., Chiang, M.H. and Chen, B., 1999. International R\&D spillovers: an application of estimation and inference in panel cointegration. Oxford Bulletin of Economics and statistics, 61(S1), pp.691-709. https://doi.org/10.1111/1468-0084.0610s1691

Keynes, J.M., 2018. The General Theory of the Rate of Interest. In The General Theory of Employment, Interest, and Money (pp. 145-153). Palgrave Macmillan, Cham. https://doi.org/10.1007/978-3-319-70344-2 13

Khan, M.S., 2011. The design and effects of monetary policy in SubSaharan African countries. Journal of African Economies, 20(suppl_2), pp.16-35. https://doì.org/10.1093/jae/ejq025

Keeley, L.H., 1988. Hunter-gatherer economic complexity and "population pressure": A cross-cultural analysis. Journal of anthropological archaeology, 7(4), pp.373-411. https://doi.org/10.1016/0278-4165(88)90003-7

Im, K.S., Pesaran, M.H. and Shin, Y., 2003. Testing for unit roots in heterogeneous panels. Journal of econometrics, 115(1), .5374 https://doi.org/10.1016/S0304-4076(03)00092-7

Levin, A., Lin, C.F. and Chu, C.S.J., 2002. Unit root tests in panel data: asymptotic and finite-sample properties. Journal of econometrics, 108(1), .1-24. https://doi.org/10.1016/S0304-4076(01)00098-7
Łyziak, T., 2010. Measurement of perceived and expected inflation on the basis of consumer survey data. Bank for Internat. Settlements.

Maddala, G.S. and Wu, S., 1999. A comparative study of unit root tests with panel data and a new simple test. Oxford Bulletin of Economics and statistics, 61(S1), pp.631-652. https://doi.org/10.1111/1468-0084.0610s1631

Mahadeva, L. and Sinclair, P., 2001, June. The transmission mechanism of monetary policy. In Materia $\prod$ przygotowany na Central Bank Governors" Symposium, Bank Anglii (8)

Metcalfe, J.S. and Foster, J. eds., 2007. Evolution and economic complexity. Edward Elgar Publishing.

Mishkin, F.S., 1995. Symposium on the monetary transmission mechanism. Journal of Economic perspectives, 9(4), pp.3-10. https://doi.org/10.1257/jep.9.4.3

Mishra, P., Montiel, P.J. and Spilimbergo, A., 2010. Monetary transmission in low income countries. IMF Working Papers, pp.1-42. https://doi.org/10.5089/9781455208883.001

Morais, B., Peydró, J.L., Roldán-Peña, J. and Ruiz-Ortega, C., 2019. The International Bank Lending Channel of Monetary Policy Rates and QE: Credit Supply, Reach-for-Yield, and Real Effects. The Journal of Finance, 74(1), pp.55-90. https://doi.org/10.1111/jofi.12735

Pedroni, P., 1999. Critical values for cointegration tests in heterogeneous panels with multiple regressors. Oxford Bulletin of Economics and statistics, 61(S1), pp.653-670. https://doi.org/10.1111/1468-0084.0610s1653

Pedroni, P., 2004. Panel cointegration: asymptotic and finite sample properties of pooled time series tests with an application to the PPP hypothesis. Econometric theory, 20(3), pp.597-625. https://doi.org/10.1017/S0266466604203073

Pesaran, M.H., 2007. A simple panel unit root test in the presence of cross-section dependence. Journal of applied econometrics, 22(2), pp.265-312 https://doi.org/10.1002/jae.951

Pétursson, T.G., 2001. The transmission mechanism of monetary policy. Monetary Bulletin, 4, pp.62-77.

Pollin, R., Epstein, G., Heintz, J. and Ndikumana, L., 2009. An employment-targeted economic program for South Africa. In Economic Alternatives for Growth, Employment and Poverty Reduction (pp. 227-240). Palgrave Macmillan, London. https://doi.org/10.1057/9780230250635 12

Simoes, A.J.G. and Hidalgo, C.A., 2011, August. The economic complexity observatory: An analytical tool for understanding the dynamics of economic development. In Workshops at the twenty-fifth AAAI conference on artificial intelligence.

Smal, M.M. and De Jager, S., 2001. The monetary transmission mechanism in South Africa. Pretoria: South African Reserve Bank.

Sterk, V. and Tenreyro, S., 2018. The transmission of monetary policy through redistributions and durable purchases. Journal of Monetary Economics, 99, pp.124-137. https://doi.org/10.1016/j.jmoneco.2018.07.003

Taylor, J., (1995), The Monetary Transmission Mechanism: An empirical framework, Journal of Economic Perspectives, 9(4), $11-26$ https://doi.org/10.1257/jep.9.4.11

Uanguta, E. and Ikhide, S., 2002. Monetary policy transmission mechanism in Namibia. Bank of Namibia Research Department.

Vernon, R., 2017. International investment and international trade in the product cycle. In International Business (pp. 99-116). Routledge. https://doi.org/10.4324/9781315199689-6 
Wuhan, L.S. and Khurshid, A., 2015. The effect of interest rate on investment; Empirical evidence of Jiangsu Province, China. Journal of International Studies Vol, 8(1). https://doi.org/10.14254/2071-8330.2015/8-1/7
Yu, J. and Lee, L.F., 2010. Estimation of unit root spatial dynamic panel data models. Econometric Theory, 26(5), pp.13321362.

https://doi.org/10.1017/S0266466609990600

Received on 01-10-2019

Accepted on 13-11-2019

Published on 27-12-2019

DOI: https://doi.org/10.6000/1929-7092.2019.08.117

(C) 2019 Ralarala and Ncanywa; Licensee Lifescience Global.

This is an open access article licensed under the terms of the Creative Commons Attribution Non-Commercial License (http://creativecommons.org/licenses/by-nc/3.0/) which permits unrestricted, non-commercial use, distribution and reproduction in any medium, provided the work is properly cited. 